\begin{tabular}{c|c|c}
\hline \hline $\begin{array}{c}\text { Vol. 4: 187-193, 2008 } \\
\text { doi: } 10.3354 / \text { esr00070 }\end{array}$ & $\begin{array}{c}\text { ENDANGERED SPECIES RESEARCH } \\
\text { Endang Species Res }\end{array}$ & Published online December 21, 2007 \\
\hline \hline
\end{tabular}

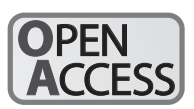

\author{
THEME SECTION The following text is a contribution to Inter-Research Symposium 1 \\ 'Satellite Tracking for the Conservation of Migratory Vertebrates' \\ held in Myrtle Beach, SC, USA in February 2007
}

\title{
Evaluating potential tagging effects on leatherback sea turtles
}

\author{
Scott A. Sherrill-Mix* ${ }^{*}$ Michael C. James \\ Department of Biology, Dalhousie University, 1355 Oxford St., Halifax, Nova Scotia B3H 4J1, Canada
}

\begin{abstract}
Although the use of satellite tracking to study the leatherback sea turtle Dermochelys coriacea continues to increase, there has been little inquiry into the effects of this research. We investigated effects of handling and tagging on leatherbacks using state-space estimated positions from 42 turtles satellite-tagged at sea. Although a control group was not available, we observed several possible effects of tagging and handling. Turtles were much more likely to begin migration, and travel speeds were significantly higher in the first week after capture. We inferred that 17 of the 42 turtles departed Canadian waters immediately after tagging. Turtles were more likely to begin their migration immediately if they were tagged later in the year, or if they were tagged following entanglement in fishing gear. Turtles that remained in the north commenced foraging after a median of $12.7 \mathrm{~d}$. We also documented reports of previously harnessed leatherbacks re-sighted on nesting beaches. Although it remains uncertain whether the observed effects are due to capture and/or tagging and whether they are detrimental to individual turtles, this study emphasizes the necessity of considering tag effects on this species.
\end{abstract}

KEY WORDS: Dermochelys coriacea - Handling effects - Tagging effects - Animal welfare · Migration · Satellite telemetry

Resale or republication not permitted without written consent of the publisher

\section{INTRODUCTION}

Satellite telemetry provides unique insight into the movements and behavior of far-ranging, deep-diving vertebrates such as the leatherback sea turtle Dermochelys coriacea. Unfortunately, attaching satellite tags to animals is not without risks and harm can be caused both by distress from capture and the physiological impacts of tagging (see Godfrey \& Bryant 2003, Hawkins 2004,Wilson \& McMahon 2006 for review).

Negative effects of capture and tagging have been observed in many marine animals. In Adélie penguins Pygoscelis adeliae, harnesses severely impaired foraging, with $87 \%$ of animals tagged late in the season abandoning their young (Watanuki et al. 1992). Tagging effects have been observed in other penguins but are reduced by using glue instead of harnesses, using smaller tags, implanting the tag surgically, and tagging earlier in the season (Wilson et al. 1986,
Watanuki et al. 1992, Hull 1997, Ballard et al. 2001, Green et al. 2004). Yet, a recent study found that even applying a leg band to a young king penguin Aptenodytes patagonicus halved the bird's survival rate (Gauthier-Clerc et al. 2004).

Tagging effects on larger animals are often less severe. No long-term effects of tagging were observed in Hawaiian monk seals Monachus schauinslandi (Baker \& Johanos 2002), or northern fur seals Callorhinus ursinus (Trites 1991), while foraging trips were $15 \%$ longer for tagged Antarctic fur seals Arctocephalus gazella (Walker \& Boveng 1995). Long-term handling effects on polar bears Ursus maritimus, were small, but short-term displacement was common (Ramsay \& Stirling 1986).

Due to their oil secretions and flexible skin-covered carapace, leatherbacks pose a significant challenge to satellite tracking research as tags cannot be glued directly to the turtle. Eckert \& Eckert (1986) designed 
padded backpack-like harnesses for leatherbacks (see Fig. 4A), which has facilitated many telemetry studies on this species (see Godley et al. 2008, this Theme Section for review).

Some evidence of tagging effects in leatherbacks has previously been reported. For example, James et al. (2006) suspected some short-term tagging effects on leatherbacks tagged at sea and excluded data from the first week of tagging from their analysis. In nesting leatherbacks, Wallace et al. (2005) observed significantly longer internesting periods and altered diving behavior in more intensively handled turtles. Troëng et al. (2006) reported soft tissue damage, including callousing from shoulder straps on a turtle wearing a harness applied 2 yr earlier. Fossette et al. (2008, this Theme Section) found that 3 leatherbacks tagged with harnesses moved slower and dived for shorter durations than 2 turtles with transmitters attached directly to their carapace.

Though easy to overlook and tempting to ignore, it is morally imperative to thoroughly study any deleterious effects of research focused on endangered species. The cost to subject animals, and therefore the population when numbers are few, must be weighted especially heavily against the benefits for science and conservation. Here, we investigate potential effects of satellitetagging through analyses of differences in movement and migration rate using positions estimated by statespace models from 42 leatherback turtles.

\section{MATERIALS AND METHODS}

If disturbances cause a leatherback to flee or interrupt foraging, the speed at which the individual moves may be an indicator of short-term tagging effects. The state-space modeled estimates of Jonsen et al. (2007) provide a useful dataset for studying post-tagging displacement. At small time scales, minor amounts of noise, common in Argos data, can greatly skew estimates of speed. The locations generated by the statespace model are the most probable estimates of a given turtle's position and should be more robust than traditional filters, which can obscure underlying patterns (Jonsen et al. 2003, 2006). In addition, a switching state-space model can estimate a turtle's behavioral mode as either foraging or transiting based on differences in turn angle and travel speed distributions (Jonsen et al. 2007) and can discriminate between turtles remaining in northern waters and turtles that have begun their southward migration, defined as continuous movement uninterrupted by foraging to below $36^{\circ} \mathrm{N}$ (Sherrill-Mix et al. 2007). In the present study, we use all available positions above $36^{\circ} \mathrm{N}$ from the first season tracks of 42 (20 mature females; 8 mature males; 14 subadults $<145 \mathrm{~cm}$ curved carapace length) turtles.
In order to separate displacement due to geostrophic currents from directed locomotion, geostrophic current velocities were obtained from weekly Maps of Absolute Dynamic Topography (MADT) from Segment Sol multimissions d'ALTimétrie, d'Orbitographie et de localisation précise) (SSALTO)/Data Unification and Altimeter Combination System (DUACS) data distributed by Aviso (see www.jason.oceanobs.com/). Current velocities at turtle positions were interpolated from these current maps. Turtle rates of travel were then adjusted by current velocity. Although these estimates are for surface currents, Gaspar et al. (2006) suggest they should provide a good approximation of the currents experienced by the turtle, as leatherbacks spend the majority of their time in epipelagic waters (Hays et al. 2004b, James et al. 2006).

To investigate any changes in travel speed during the tracking, the effects of week after capture as a categorical variable and whether the turtle was migrating or still foraging on individual rates of travel were modeled using a generalized linear mixed-effects model. As travel speed is a positive continuous variable, speed was modeled using a Gamma distribution with an identity link. As each turtle was measured more than once, a random effect for individual turtles and a firstorder autoregressive structure was included.

Many turtles appear to leave northern waters immediately after tagging without inferred foraging. To investigate this phenomenon, we modeled the probability of immediate departure using a generalized linear model with a binomial distribution. Date of tagging, carapace length, maturity, sea surface temperature at release, day length, tagging location (waters off Halifax [ca. $44^{\circ} \mathrm{N}, 64^{\circ} \mathrm{W}$ ] or Cape Breton Island [ca. $47^{\circ} \mathrm{N}, 60^{\circ} \mathrm{W}$, Nova Scotia, Canada), sex and whether the turtle had been entangled in fishing gear prior to tagging were selected using stepwise regression based on the Akaike information criterion (AIC). All analyses were performed in $\mathrm{R}$ (Version 2.4).

When discussing the results of binomial regression analysis, it is useful to think of probability in terms of odds $(\mathrm{p} /(1-\mathrm{p}))$ where $\mathrm{p}$ is the probability of an event, e.g. a turtle departing without feeding. For example, if the probability of immediate departure is 0.25 , the odds of immediate departure will be 0.333 (1:3).

In addition to investigating signs of tagging in the telemetry data, we also collected reports of turtles originally tagged with harnesses, flipper tags and implanted microchips in Canadian waters that were reobserved on nesting beaches (James et al. 2007).

\section{RESULTS}

Positions from 11996 six-hour tracking periods were available, and geostrophic currents were obtained for 
11590 positions. Both time after capture and whether the turtle was migrating south were significantly related to leatherback speed in the generalized linear mixed-effect model. The mean speed of migrating turtles determined by the model was $2.69 \mathrm{~km} \mathrm{~h}^{-1}(95 \%$ Confidence Interval, CI: 2.23 to $2.84 \mathrm{~km} \mathrm{~h}^{-1}$ ) and the estimated speed of turtles remaining in the north was $1.37 \mathrm{~km} \mathrm{~h}^{-1}$ (95\% CI: 1.23 to $1.51 \mathrm{~km} \mathrm{~h}^{-1}$ ).

The first week after capture was the only week in which the speed of turtles remaining in the north was not significantly slower than that of migrating turtles (Fig. 1), with the mean speed of turtles remaining in the north $1.11 \mathrm{~km} \mathrm{~h}^{-1}$ (95\% CI: 0.90 to $1.31 \mathrm{~km} \mathrm{~h}^{-1}$ ) faster than in the remaining weeks. The second week after capture also showed a smaller but still significant increase of $0.52 \mathrm{~km} \mathrm{~h}^{-1}$ ( $95 \%$ CI: 0.37 to $0.66 \mathrm{~km} \mathrm{~h}^{-1}$ ) over the remaining weeks (Fig. 1).

Immediate departure without foraging was inferred in 17 of the 42 turtles. A precipitous peak in migration departure can be seen immediately after capture in Fig. 2. This large pulse of departures sharply contrasts the gradual migration rate in the remaining days.

Date of tagging and whether the turtle was tagged following entanglement in fishing gear were related to the probability of foraging before southward migration based on the AIC (Table 1).

Each day later in the year increased the odds of immediate southward migration by $19.7 \%$ (95\% CI: 7.11 to $33.8 \%$ ) (Fig. 3). The odds of immediate migration for turtles captured in fishing gear before tagging were 503 (95\% CI: 2.11 to 120200$)$ times higher than in unentangled turtles (Fig. 3). For turtles that did not

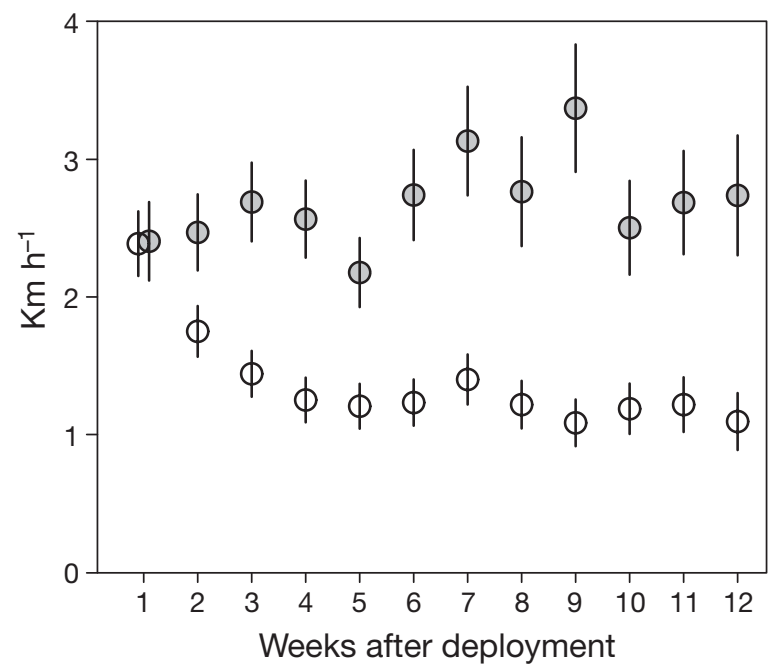

Fig. 1. Dermochelys coriacea. Comparison between the mean speed of migrating leatherbacks $(O)$ and turtles remaining in northern waters $(O)$ in relation to week after capture as predicted by a generalized linear mixed-effect model based on migration status and week. Vertical lines indicate $95 \%$ confidence intervals

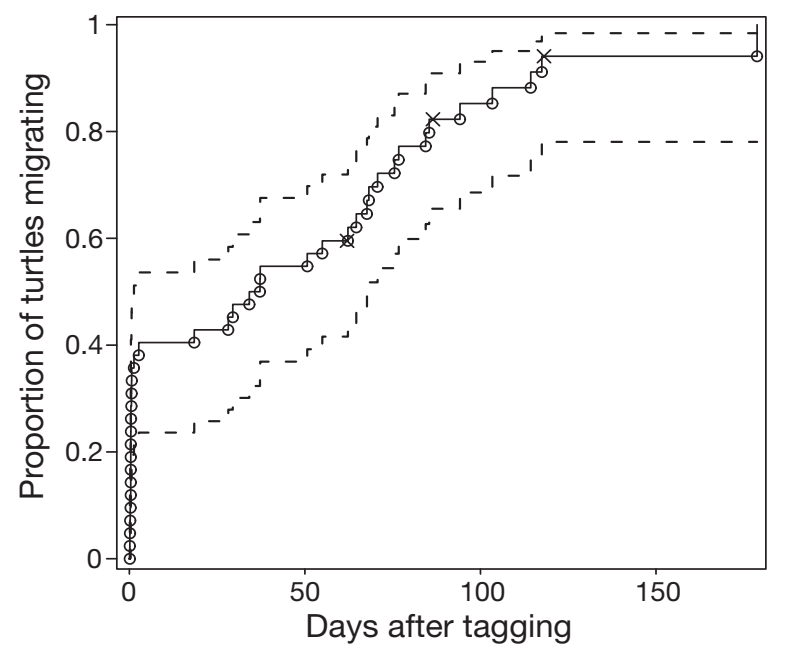

Fig. 2. Dermochelys coriacea. Predicted proportion of leatherback turtles migrating in relation to days after tagging (solid line). (O) migration departures $(\mathrm{n}=39) ;(\mathrm{x})$ tag or harness failures before migration was observed $(n=3)$. Dashed lines indicate $95 \%$ confidence intervals

Table 1. Dermochelys coriacea. Results from stepwise generalized linear modeling of the probability of foraging before southward migration for leatherbacks tagged off Nova Scotia

\begin{tabular}{|lccc|}
\hline Variable & $\beta$ & $\begin{array}{c}\text { Standard } \\
\text { error }\end{array}$ & $\mathrm{p}$ value \\
\hline $\begin{array}{l}\text { Date of tagging } \\
\text { Fishery interaction }\end{array}$ & 0.18 & 0.057 & 0.0015 \\
& 6.22 & 2.79 & 0.02 \\
\hline
\end{tabular}

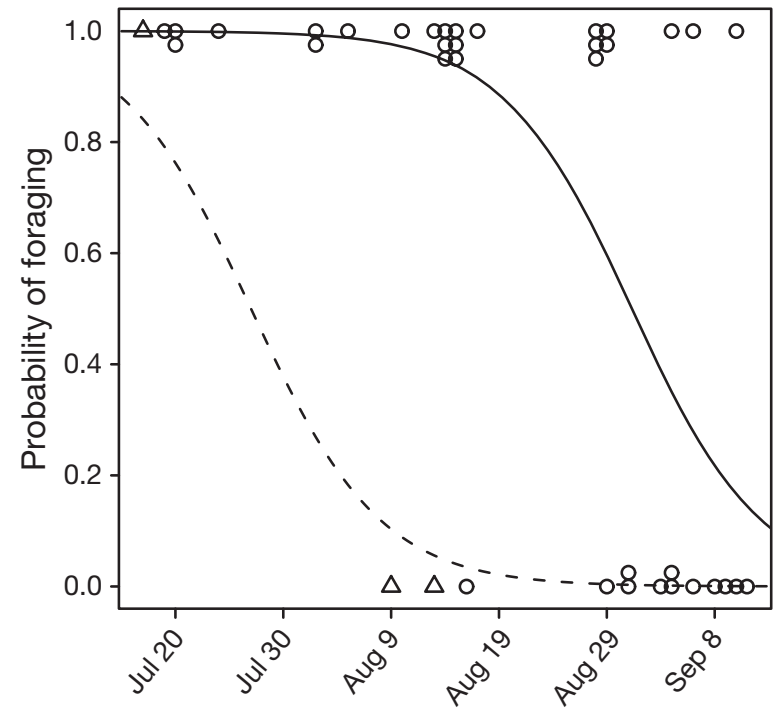

Fig. 3. Dermochelys coriacea. Predicted probability of foraging before southward migration for leatherback turtles tagged on a given date after incidental capture in fishing gear $(\Delta, \mathrm{n}=3)$ and direct capture by the field research team $(\mathrm{O}, \mathrm{n}=39)$. Lines indicate predicted probability of foraging for direct-captured (solid lines) and fishing gear-entangled (dashed lines) turtles 
migrate immediately, the median time until inferred foraging was $12.7 \mathrm{~d}$ (range: 0.175 to $48.9 \mathrm{~d}$ ) after release and the median length of stay after release was $67.7 \mathrm{~d}$ (range: 18.2 to $178.5 \mathrm{~d}$ ).

Ten satellite-tagged turtles were re-observed on nesting beaches in Colombia (1), French Guiana (1), Panama (3), Suriname (2), and Trinidad (3) from 0.6 to $3.8 \mathrm{yr}$ after tagging. Of these turtles, 6 were observed on beaches in the nesting season immediately following their capture in Canadian waters, including 5 that had departed northern waters without inferred foraging.

Only 2 of the 10 initial resightings of satellite-tagged turtles on nesting beaches included reports of unusual markings. One turtle had retained its harness $635 \mathrm{~d}$ after tagging. The harness had slipped slightly to one side of the carapace and the turtle had calluses on both shoulders (Fig. 4B). Grooves associated with the elastic harness tensioning ring were visible in the carapace ridges, the medial ridge had a reduced profile in the area immediately below the plastic plate holding the transmitter, and the shell had conformed slightly to the strap spanning the girth of the turtle, such that the outline of where the strap had been was slightly indented, particularly over the lowermost ridge on each side of the carapace (Fig. 4C). Biofouling on the transmitter was limited to a few barnacles and other epibionts, likely a result of painting the entire platform and tag with antifouling paint. The harness was removed and the turtle was observed nesting (M. Ramjattan pers. comm.). The same turtle was observed nesting again 2 yr later, with the only damage noted being a scar on the middle ridge of the carapace (S. Eckert, pers. comm.). Another nesting turtle was observed without its harness by S. Eckert $1011 \mathrm{~d}$ after tagging in Canada. This turtle retained small grooves in its carapace ridges and a depression in its carapace where the transmitter plate had been (Fig. 4D).

\section{DISCUSSION}

Short-term effects of handling on leatherbacks can be seen in the increased median speed of non-migrating turtles in the first and second weeks after capture. This short-term displacement seemed to have disrupted foraging, which did not commence until a median of $12.7 \mathrm{~d}$ after tagging.
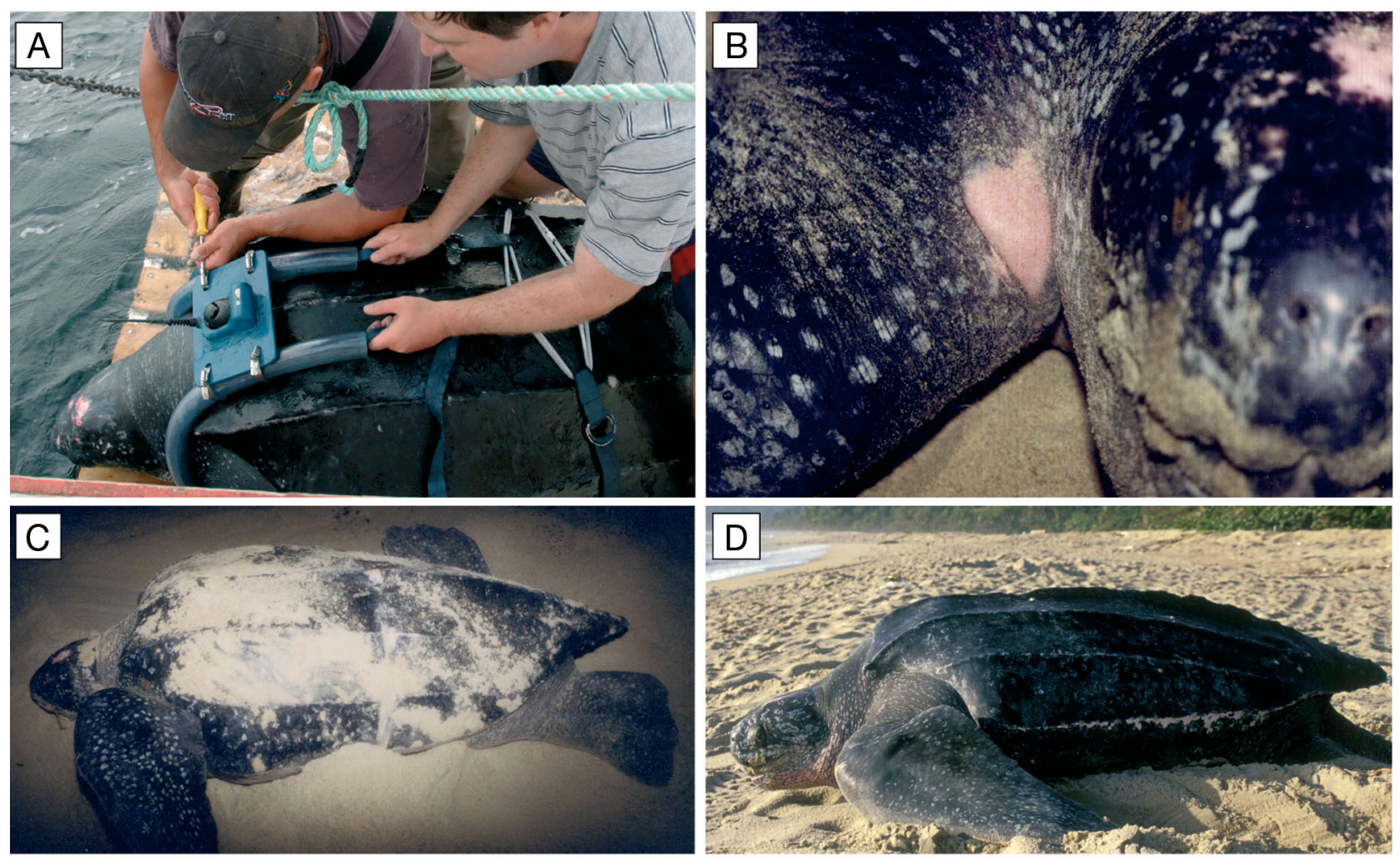

Fig. 4. Dermochelys coriacea. (A) A leatherback turtle being fitted with a harness after capture in Canadian waters; (B) close-up of the shoulder callus of (C) a nesting leatherback photographed immediately after a 635 d harness deployment (Photo: S. Pearce); (D) a nesting leatherback observed an unknown time after harness release and $1011 \mathrm{~d}$ after satellite tagging in Canadian waters (Photo: S. A. Eckert - WIDECAST) 
With $40 \%$ of tagged turtles departing immediately after capture, it appears that capture or tagging in northern waters can also trigger southward migration. Turtles captured later in the year are more likely to depart without inferred foraging. Whether this is due to the turtle already having obtained sufficient food stores or seasonal increases in migratory restlessness is unknown. Although tagging has been known to cause the delay or abortion of migration (Bernard et al. 1999, Olney et al. 2006), this is the first report of tagging potentially triggering migration.

If immediate departure from northern foraging grounds is detrimental, then our results demonstrate that tag effects could be reduced by tagging earlier in the year and not tagging leatherbacks after entanglement in fishing gear. This would have the added benefit of yielding more behavioral data from northern waters. The results presented here suggest that to achieve a $50 \%$ chance of northern foraging, turtles in the NW Atlantic should be tagged prior to August 30 or, if obtained from fishing gear, prior to July 26. If a $95 \%$ probability of northern foraging is desired, turtles would have to be tagged before August 13 or, for incidentally caught turtles, earlier than July 9.

Several studies appear to indicate that reproductive efforts in leatherbacks are largely uninterrupted by harnessing. Most males equipped with harnesses in Canadian waters migrate to breeding areas in the months after tagging (James et al. 2005a). Females harnessed on nesting beaches are often observed nesting again in the same season (e.g. Eckert et al. 2006, Benson et al. 2007). Of 34 juveniles and females satellite-tagged in Canada, 10 have been re-sighted while nesting, a re-encounter rate higher than recapture rates reported on many nesting beaches (Girondot \& Fretey 1996, Hughes 1996, Steyermark et al. 1996). In addition, turtles observed after harness release appeared generally unharmed. Although this evidence suggests that tagging is not a major detriment, effects on turtle health should not be ruled out, as the reptile reproductive cycle is robust to moderate stressors (Moore \& Jessop 2003).

Proper harnessing techniques may reduce tagging effects. With an estimated energetic cost of migration of 1.2 million cal (Wallace et al. 2006) and lipids providing approximately $8.6 \mathrm{cal} \mathrm{g}^{-1}$ (Henen 1997), turtles would be expected to lose at least $139 \mathrm{~kg}$ of body fat over the course of their migration. James et al. (2005b) found that turtles measured during the foraging season in Canadian waters were indeed $33 \%$ heavier than turtles measured on nesting beaches. When harnessing turtles, this dramatic change in mass must be accounted for by including elastic materials. Although it is tempting to try to maximize data collection and equipment retrieval by omitting a release mechanism
(Hays et al. 2004a, Troëng et al. 2006), we feel corrodible links should be an essential component of all harnesses, as recapture can not be guaranteed. In addition, we recommend using plastic tubing on all harness straps, including the strap spanning the plastron, and applying antifouling paint to the tag and tag platform.

Although harnesses built with corrodible links and sized correctly appear unlikely to cause severe harm to turtles, it may be time to consider alternatives to the harness. Tag technology has progressed greatly since studies began and current tags are only a fraction of the size of the originals. Direct attachment to the carapace using bone screws or nylon ties is becoming more enticing with decreasing tag size (Lutcavage et al. 2001, Fossette et al. 2008, this Theme Section). Fossette et al. (2008) report that turtles tagged with a direct attachment moved faster and dove for longer periods of time than harnessed turtles, although it should be noted that migrating harnessed turtles in our study had an estimated average speed $25 \%$ faster than the direct-attachment turtles studied by Fossette et al. (2008). As the manufacturing and application of harnesses is time consuming, further evaluation of this technique might benefit both researchers and leatherbacks.

Without a control group, assessing the effects of tagging on leatherbacks is difficult, and several questions remain. For example, whether there are behavioral differences between tagged turtles and the natural population, is still uncertain. In the present study, the effects of harnessing and of capture could not be differentiated. It is therefore not clear whether the migration and speed effects observed in this study occur in all handled turtles, or only among those equipped with harnesses.

If handling alone increases the chance of migration departure, and immediate departure is harmful to the turtle, then any capture of turtles during the foraging season could be deleterious. In addition, although leatherbacks are often released alive from fishing gear and assumed to be relatively unharmed, this study highlights potential post-capture effects for these animals. It would be interesting to observe whether these increases in speed and probability of migration are also observed in turtles tagged through direct attachment or using short-term tags.

Our results suggest that satellite tagging of leatherbacks at sea may result in short-term displacement and disruption of foraging. Given these possibilities and the potential long-term effects of premature migration, researchers must take care that their research does not harm the very animals they are trying to conserve. We hope that satellite tags and tag attachment methods will be further developed to minimize the fitness costs of research on these animals. 
Acknowledgements. We thank the following organizations for reporting nesting observations of leatherbacks originally equipped with satellite transmitters in Canadian waters: Asociación Anai (Costa Rica), Caribbean Conservation Corporation, Groupo Chibiqui (Colombia), Institute for Tropical Ecology and Conservation (Panama), Nature Seekers (Trinidad), NC-IUCN Leatherback Monitoring and Research Project (Suriname), and World Wildlife Fund Guianas. Special thanks to the late R. Myers for contributing greatly to this work and S. Eckert (WIDECAST) for harnesses used in our studies of leatherbacks and for indispensable advice regarding this technology. We thank B. Fricker, H. Fricker, J. Fricker, K. Martin and B. Mitchell for their instrumental contributions to all aspects of fieldwork. Thanks are also extended to I. Jonsen and W. Blanchard for statistical assistance. This research was supported by the Census of Marine Life-FMAP, Fisheries and Oceans Canada, Endangered Species Recovery Fund (World Wildlife Fund Canada and Environment Canada), National Marine Fisheries Service (USA), Natural Sciences and Engineering Research Council of Canada and the Pew Charitable Trust.

\section{LITERATURE CITED}

Baker JD, Johanos TC (2002) Effects of research handling on the endangered Hawaiian monk seal. Mar Mamm Sci 18:500-512

Ballard G, Ainley DG, Ribic CA, Barton KR (2001) Effect of instrument attachment and other factors on foraging trip duration and nesting success of Adélie penguins. Condor 103:481-490

Benson SR, Kisokau KM, Ambio L, Rei V, Dutton PH, Parker D (2007) Beach use, internesting movement, and migration of leatherback turtles, Dermochelys coriacea, nesting on the north coast of Papua New Guinea. Chelonian Conserv Biol 6:7-14

Bernard DR, Hasbrouck JJ, Fleischman SJ (1999) Handlinginduced delay and downstream movement of adult chinook salmon in rivers. Fish Res 44:37-46

Eckert SA, Eckert KL (1986) Harnessing leatherbacks. Mar Turtle Newsl 37:1-3

Eckert SA, Bagley D, Kubis S, Ehrhart L, Johnson C, Stewart $\mathrm{K}$, DeFreese D (2006) Internesting and postnesting movements and foraging habitats of leatherback sea turtles (Dermochelys coriacea) nesting in Florida. Chelonian Conserv Biol 5:239-248

Fossette S, Corbel H, Gaspar P, Le Maho Y, Georges JY (2008) An alternative technique for the long-term satellite tracking of leatherback turtles. Endang Species Res 4:33-41

Gaspar P, Georges JY, Fossette S, Lenoble A, Ferrarol S, Le Maho Y (2006) Marine animal behaviour: neglecting ocean currents can lead us up the wrong track. Proc R Soc Lond Ser B Biol Sci 273:2697-2702

Gauthier-Clerc M, Gendner JP, Ribic CA, Fraser WR and others (2004) Long-term effects of flipper bands on penguins. Proc R Soc Lond Ser B Biol Sci 271:S423-S426

Girondot M, Fretey J (1996) Leatherback turtles, Dermochelys coriacea, nesting in French Guiana, 1978-1995. Chelonian Conserv Biol 2:204-208

Godfrey JD, Bryant DM (2003) Effects of radio transmitters: review of recent radio-tracking studies. In: Williams M (ed) Conservation applications of measuring energy expenditure of New Zealand birds: assessing habitat quality and costs of carrying radio transmitters. Sci Conserv 214:83-95

- Godley BJ, Blumenthal JM, Broderick AC, Coyne MS, Godfrey MH, Hawkes LA, Witt MJ (2008) Satellite tracking of sea turtles: Where have we been and where do we go next? Endang Species Res 4:3-22

Green JA, Tanton JL, Woakes AJ, Boyd IL, Butler PJ (2004) Effects of long-term implanted data loggers on macaroni penguins Eudyptes chrysolophus. J Avian Biol 35:370-376

Hawkins P (2004) Bio-logging and animal welfare: practical refinements. Mem Natl Inst Polar Res 58:58-68

Hays GC, Houghton JDR, Isaacs C, King RS, Lloyd C, Lovell P (2004a) First records of oceanic dive profiles for leatherback turtles, Dermochelys coriacea, indicate behavioural plasticity associated with long-distance migration. Anim Behav 67:733-743

Hays GC, Houghton JDR, Myers AE (2004b) Pan-Atlantic leatherback turtle movements. Nature 429:522

Henen BT (1997) Seasonal and annual energy budgets of female desert tortoises (Gopherus agassizii). Ecology 78:283-296

Hughes GR (1996) Nesting of the leatherback turtle (Dermochelys coriacea) in Tongaland, KwaZulu-Natal, South Africa, 1963-1995. Chelonian Conserv Biol 2:153-158

Hull CL (1997) The effect of carrying devices on breeding royal penguins. Condor 99:530-534

James MC, Eckert SA, Myers RA (2005a) Migratory and reproductive movements of male leatherback turtles (Dermochelys coriacea). Mar Biol 147:845-853

James MC, Ottensmeyer CA, Myers RA (2005b) Identification of high-use habitat and threats to leatherback sea turtles in northern waters: new directions for conservation. Ecol Lett 8:195-201

James MC, Ottensmeyer CA, Eckert SA, Myers RA (2006) Changes in diel diving patterns accompany shifts between northern foraging and southward migration in leatherback turtles. Can J Zool 84:754-765

James MC, Sherrill-Mix SA, Myers RA (2007) Population characteristics and seasonal migrations of leatherback sea turtles at high latitudes. Mar Ecol Prog Ser 337: 245-254

Jonsen ID, Myers RA, Mills Flemming J (2003) Meta-analysis of animal movment using state-space models. Ecology 84:3055-3063

Jonsen ID, Myers RA, James MC (2006) Robust hierarchical state-space models reveal diel variation in movement rates of migrating leatherback turtles. J Anim Ecol 75: 1046-1057

Jonsen ID, Myers RA, James MC (2007) Identifying leatherback turtle foraging behaviour from satellite telemetry using a switching state-space model. Mar Ecol Prog Ser 337:255-264

Lutcavage M, Rhodin AGJ, Sadove SS, Conroy CR (2001) Direct carapacial attachment of satellite tags using orthopedic bioabsorbable mini-anchor screws on leatherback turtles in Culebra, Puerto Rico. Mar Turtle Newsl 95:9-12

Moore IT, Jessop TS (2003) Stress, reproduction and andrenocortical modulation in amphibians and reptiles. Horm Behav 43:39-47

Olney JE, Latour RJ, Watkins BE, Clarke DG (2006) Migratory behavior of American shad in the York River, Virginia, with implications for estimating in-river exploitation from tag recovery data. Trans Am Fish Soc 135:889-896

Ramsay MA, Stirling I (1986) Long-term effects of drugging and handling free-ranging polar bears. J Wildl Manag 50:619-626

Sherrill-Mix SA, James MC, Myers RA (2007) Migration cues and timing in leatherback sea turtles. Behav Ecol; doi: 10.1093/beheco/arm104

Steyermark AC, Williams K, Spotila JR, Paladino FV and others (1996) Nesting leatherback turtles at Las Baulas National Park, Costa Rica. Chelonian Conserv Biol 2: 173-183 
Trites AW (1991) Does tagging and handling affect the growth of northern fur seal pups (Callorhinus ursinus)? Can J Fish Aquat Sci 48:2436-2442

Troëng S, Solano R, Díaz-Merry A, Ordoñez J and others (2006) Report on long-term transmitter harness retention by a leatherback turtle. Mar Turtle Newsl 111:6-7

Walker BG, Boveng PL (1995) Effects of time-depth recorders on maternal foraging and attendance behavior of Antarctic fur seals (Arctocephalus gazella). Can J Zool 73: 1538-1544

Wallace BP, Williams CL, Paladino FV, Morreale SJ, Lindstrom RT, Spotila JR (2005) Bioenergetics and diving activity of internesting leatherback turtles Dermochelys coriacea at Parque Nacional Marino Las Baulas, Costa Rica. J Exp Biol 208:3873-3884

Editorial responsibility: Brendan Godley (Editor-in-Chief), University of Exeter, Cornwall Campus, UK
Wallace BP, Kilham SS, Paladino FV, Spotila JR (2006) Energy budget calculations indicate resource limitation in Eastern Pacific leatherback turtles. Mar Ecol Prog Ser 318: 263-270

Watanuki Y, Mori Y, Naito Y (1992) Adélie penguin parental activities and reproduction: effects of device size and timing of its attachment during chick rearing period. Polar Biol 12:539-544

Wilson RP, McMahon CR (2006) Measuring devices on wild animals: what constitutes acceptable practice? Front Ecol Environ 4:147-154

Wilson R, Grant W, Duffy D (1986) Recording devices on freeranging marine animals: does measurement affect foraging performance? Ecology 67:1091-1093

Submitted: September 7, 2007; Accepted: November 6, 2007 Proofs received from author(s): December 14, 2007 